\title{
Halorubrum tibetense sp. nov., a novel haloalkaliphilic archaeon from Lake Zabuye in Tibet, China
}

\author{
Huapeng Fan, ${ }^{1}$ Yanfen Xue, ${ }^{1}$ Yanhe Ma, ${ }^{1}$ Antonio Ventosa ${ }^{2}$ \\ and William D. Grant ${ }^{3}$ \\ ${ }^{1}$ Department of Microbial Physiology and Ecology, Institute of Microbiology, Chinese Academy \\ of Sciences, Beijing 100080, China \\ ${ }^{2}$ Department of Microbiology and Parasitology, Faculty of Pharmacy, University of Sevilla, \\ 41012 Sevilla, Spain \\ ${ }^{3}$ Department of Microbiology and Immunology, University of Leicester, Leicester LE1 9HN, UK
}

Correspondence

Yanhe Ma

mayanhe@sun.im.ac.cn
Based on the analysis of $16 \mathrm{~S}$ rRNA gene sequences, the genus Halorubrum was formally proposed by McGenity \& Grant (1995) to accommodate several species previously included in the genus Halobacterium: Halorubrum trapanicum NRC $34021^{\mathrm{T}}$ (Petter, 1931), Halorubrum saccharovorum (Tomlinson \& Hochstein, 1976), Halorubrum sodomense (Oren, 1983) and Halorubrum lacusprofundi (Franzmann et al., 1988). Subsequently, Oren \& Ventosa (1996) transferred Halorubrobacterium coriense (Kamekura \& Dyall-Smith, 1995) and Halorubrobacterium distributum (Zvyagintseva \& Tarasov, 1987) to the genus Halorubrum. Natronobacterium vacuolatum (Mwatha \& Grant, 1993) was also reassigned into Halorubrum as Halorubrum vacuolatum by Kamekura et al. (1997). More recently, a novel species of the genus Halorubrum, Halorubrum tebenquichense, has been described (Lizama et al., 2002). The aim of this study was to describe a novel haloalkaliphilic archaeon isolated from the Lake Zabuye in Tibet, China and we propose a novel species, Halorubrum tibetense sp. nov.

Abbreviations: PG, phosphatidylglycerol; PGP-Me, phosphatidylglycerol phosphate methyl ester; PGS, phosphatidylglycerol sulfate; S-DGD, sulfated diglycosyl diether.

The GenBank accession number for the 16S rRNA gene sequence of strain $8 W 8^{\top}$ is $A Y 149598$.
Lake Zabuye $\left(31^{\circ} 20^{\prime} \mathrm{N} 84^{\circ} 05^{\prime} \mathrm{E}\right)$ is located on the Tibetan Plateau $4421 \mathrm{~m}$ above sea level. It is an alkaline chloride-

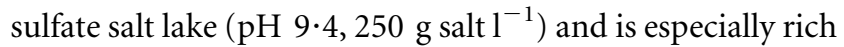
in lithium ions $\left(0 \cdot 1 \mathrm{~g} \mathrm{l}^{-1}\right.$; Holland et al., 1991). During a broad study of characterization of haloarchaea isolated from Lake Zabuye, strain $8 \mathrm{~W} 8^{\mathrm{T}}$ was isolated using a complex medium containing $\left(\mathrm{g} \mathrm{l}^{-1}\right)$ : Casamino acids (Difco), 7.5; yeast extract (Difco), 10.0; trisodium citrate, 3.0; $\mathrm{MgSO}_{4} .7 \mathrm{H}_{2} \mathrm{O}, 1 \cdot 0 ; \mathrm{KCl}, 10 \cdot 0 ; \mathrm{LiCl}, 0 \cdot 1 ; \mathrm{Fe}^{2+}$ and $\mathrm{Mn}^{2+}$, trace; $\mathrm{NaCl}, 200 ; \mathrm{Na}_{2} \mathrm{CO}_{3}, 10 \cdot 0$. The method used for enrichment and isolation was described previously (Tindall et al., 1980). Cells of strain $8 \mathrm{~W} 8^{\mathrm{T}}$ were irregular, rodshaped and non-motile, as determined by phase-contrast and electron microscopy (Fig. 1).

The methods used for genomic DNA preparation, PCR amplification of $16 \mathrm{~S}$ rRNA gene and the gene sequencing were described previously (McGenity \& Grant, 1993). The almost complete $16 \mathrm{~S}$ rDNA sequence (1470 bp) of strain $8 \mathrm{~W} 8^{\mathrm{T}}$ was determined and compared to the sequences of members of the genus Halorubrum and other closely related haloarchaea. The phylogenetic analysis was performed by the neighbour-joining method with the Kimura twoparameter calculation model in TREECONW version $1.3 \mathrm{~b}$ (Van de Peer \& De Wachter, 1994) after multiple alignment 


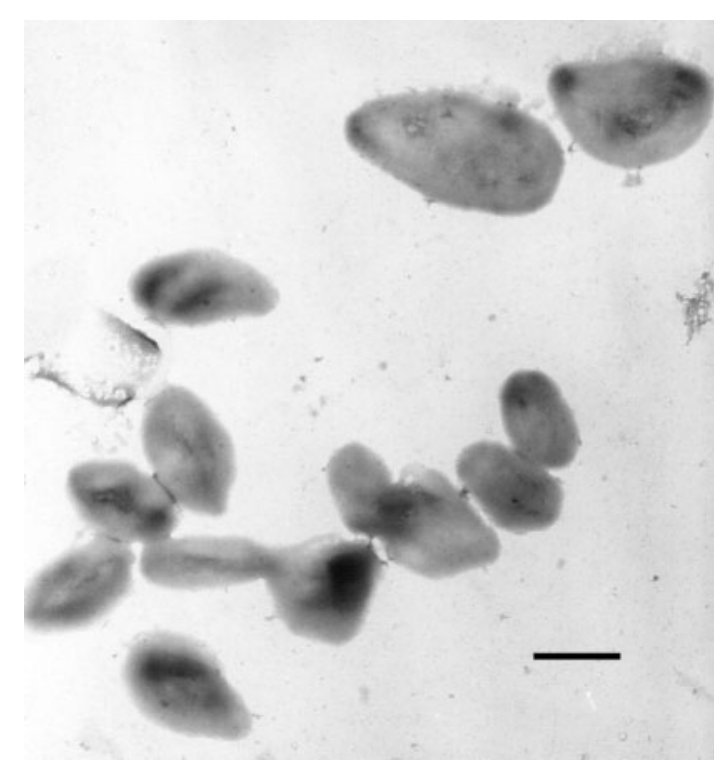

Fig. 1. Electron micrograph showing the morphology of cells of strain $8 \mathrm{~W} 8^{\top}$. Bar, $1 \mu \mathrm{m}$.

of data by CLUSTAL W version 1.8 (Thompson et al., 1994). Positions with any gaps and alignment uncertainty were omitted from the analysis. The 1412 unambiguous nucleotides were used for computing evolutionary distance. The phylogenetic tree (Fig. 2) indicated that strain $8 \mathrm{~W} 8^{\mathrm{T}}$ clustered with the species of the genus Halorubrum and constituted a subgroup with one described haloalkaliphilic species (Halorubrum vacuolatum JCM $9060^{\mathrm{T}}$ ). Sequence similarity calculations after a neighbour-joining analysis indicated that strain $8 \mathrm{~W}^{\mathrm{T}}$ was related to Halorubrum vacuolatum $(96 \cdot 7 \%$ sequence similarity), Halorubrum saccharovorum (96.0\%), Halorubrum lacusprofundi (95.4\%), Halorubrum sodomense $(95.3 \%)$, and other species of Halorubrum (93.5-95.0\%). Lower sequence similarities $(<90.0 \%)$ were found with all species of the other genera of Halobacteriales. Moreover, the 16S rDNA sequence of strain $8 \mathrm{~W} 8^{\mathrm{T}}$ possessed signature sequences of the genus
Halorubrum: 199-229, 656-672 and 1242-1259 (positions based on the sequence of Escherichia coli) and 11 of 14 signature bases specific for Halorubrum (Grant et al., 2001).

Results of the chemotaxonomic analyses are given in the species description and Table 1. The polar lipid profile of strain $8 \mathrm{~W} 8^{\mathrm{T}}$ (Fig. 3), analysed by thin-layer chromatography as previously described (Ross et al., 1981), was similar to that of Halorubrum vacuolatum (Mwatha \& Grant, 1993). Glycolipid and phosphatidylglycerol sulfate (PGS) were not present in these two species, whereas PGS was present in other species of Halorubrum. This feature would imply that the genus Halorubrum constitutes a heterogeneous group. As shown in Table 1, the genus Halorubrum contains non-alkaliphilic, facultatively alkaliphilic and obligately alkaliphilic species and they show different polar lipid compositions. Non-alkaliphilic members contained sulfated diglycosyl diether (S-DGD) and PGS besides phosphatidylglycerol (PG) and phosphatidylglycerol phosphate methyl ester (PGP-Me); facultatively alkaliphilic members had SDGD besides PG and PGP-Me and obligately alkaliphilic members contained only PG and PGP-Me.

The results of the physiological characterization are given in the species description. The methods used were in accordance with the recommended minimal standards for description of new taxa in the haloarchaea (Oren et al., 1997). DNA-DNA reassociation values were determined with strain $8 \mathrm{~W} 8^{\mathrm{T}}$ and the type strains of closely related Halorubrum species using the spectrophotometric renaturation rate method (Huß et al., 1983). Strain $8 \mathrm{~W} 8^{\mathrm{T}}$ showed relatively low DNA-DNA hybridization percentages to the type strain of Halorubrum saccharovorum ATCC $29252^{\mathrm{T}}$ (22\%), Halorubrum vacuolatum JCM $9060^{\mathrm{T}}(19 \%)$, Halorubrum sodomense NCIMB $2197^{\mathrm{T}}(14 \%)$ and Halorubrum lacusprofundi JCM $8891^{\mathrm{T}}$ (14\%).

Overall, our data show that strain $8 \mathrm{~W} 8^{\mathrm{T}}$ represents a novel organism of the genus Halorubrum and we propose to place it in a novel species with the name Halorubrum tibetense sp. nov.

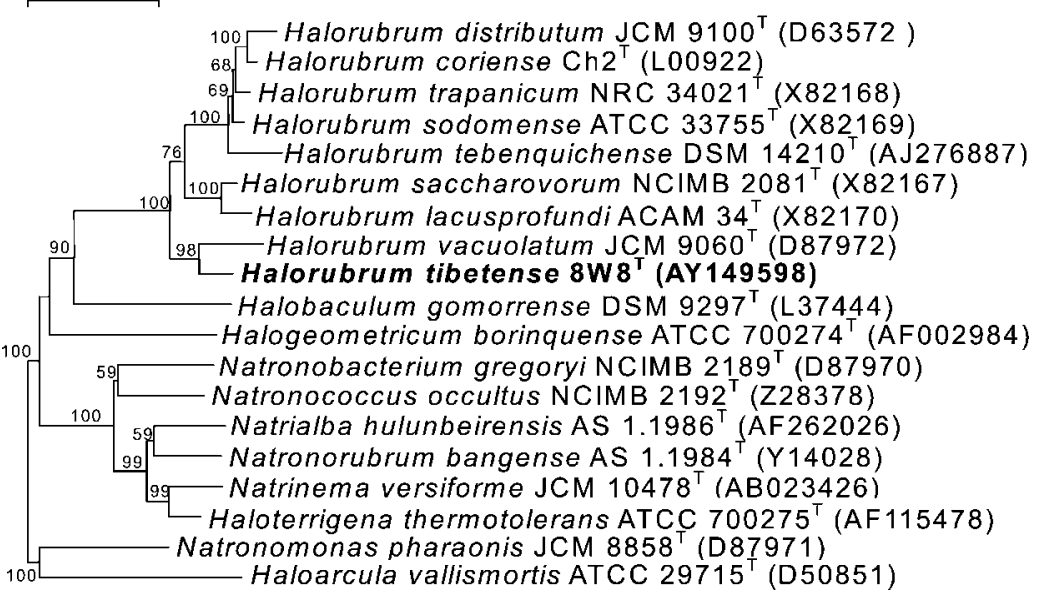

Fig. 2. Phylogenetic analysis based on $16 \mathrm{~S}$ rRNA gene sequences available from GenBank databases (accession numbers in parentheses). Bootstrap values based on 100 replications are listed as percentages at the branching points. Scale bar, 0.05 expected changes per site.
} 
Table 1. Phenotypic characteristics of strain $8 \mathrm{~W} 8^{\top}$ and some related Halorubrum species

Species: 1, Halorubrum vacuolatum; 2, Halorubrum saccharovorum; 3, Halorubrum lacusprofundi; 4, Halorubrum sodomense; 5, Halorubrum coriense; 6, Halorubrum distributum; 7, Halorubrum trapanicum NRC $34021^{\mathrm{T}}$; 8, Halorubrum tebenquichense. +, Positive; -, negative; $\mathrm{ND}$, not determined.

\begin{tabular}{|c|c|c|c|c|c|c|c|c|c|}
\hline Characteristic & $8 W 8^{T}$ & 1 & 2 & 3 & 4 & 5 & 6 & 7 & 8 \\
\hline Gas vacuoles & - & + & - & - & - & - & - & - & $\mathrm{ND}$ \\
\hline $\mathrm{Mg}^{2+}$ requirement & - & - & + & + & + & + & ND & ND & - \\
\hline Growth at $\mathrm{pH} 7 \cdot 0$ & - & - & + & + & + & + & + & + & + \\
\hline Growth at $\mathrm{pH} 10 \cdot 0$ & + & + & - & - & - & - & - & - & + \\
\hline Starch hydrolysis & - & - & - & - & + & ND & - & - & - \\
\hline \multicolumn{10}{|l|}{ Utilization of: } \\
\hline Glucose & + & + & + & + & + & + & - & + & + \\
\hline Galactose & - & + & + & + & - & + & - & + & + \\
\hline Sucrose & + & + & + & $\mathrm{ND}$ & + & + & - & + & $\mathrm{ND}$ \\
\hline Lactose & + & $\mathrm{ND}$ & + & + & - & + & ND & - & $\mathrm{ND}$ \\
\hline $\mathrm{G}+\mathrm{C}$ content $(\mathrm{mol} \%)^{*}$ & $63 \cdot 3^{a}$ & $62 \cdot 7^{a}$ & $71 \cdot 2^{b}$ & $65 \cdot 8^{b}$ & $67 \cdot 4^{b}$ & $\mathrm{ND}$ & $63 \cdot 6$ & $64 \cdot 3^{b}$ & $63 \cdot 2^{a}$ \\
\hline
\end{tabular}

${ }^{\star} \mathrm{G}+\mathrm{C}$ content was measured by melting temperature $(a)$ or buoyant density $(b)$.

\section{Description of Halorubrum tibetense sp. nov.}

Halorubrum tibetense (ti.be.ten'se. N.L. neut. adj. tibetense from Tibet).

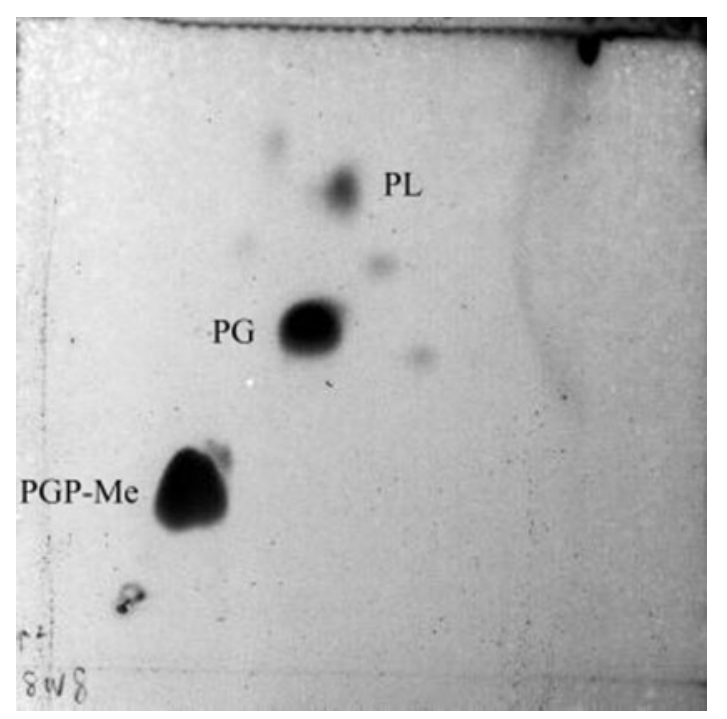

Fig. 3. Polar lipid pattern of strain $8 W 8^{\top}$ by two-dimensional TLC. PG, Phosphatidylglycerol; PGP-Me, phosphatidylglycerol phosphate methyl ester; PL, unidentified phospholipids. The origin is in the bottom left corner.
Cells are irregular rod-shaped $(0 \cdot 5-1 \times 1 \cdot 5-2 \cdot 5 \mu \mathrm{m})$. Gramnegative. Cells lyse in medium with less than $1.5 \mathrm{M} \mathrm{NaCl}$. Colonies are $0.5-1 \mathrm{~mm}$ in diameter, red-pigmented, smooth, circular and convex. Haloalkaliphilic. Growth occurs optimally at $3 \cdot 0-3 \cdot 4 \mathrm{M} \mathrm{NaCl}$. The $\mathrm{pH}$ range for growth is $8 \cdot 0-10 \cdot 5$, with optimum $\mathrm{pH} 9 \cdot 0-9 \cdot 5$. Optimal temperature for growth is $37-40{ }^{\circ} \mathrm{C}$. Magnesium is not required for growth. Chemo-organotrophic and strictly aerobic. Catalase- and oxidase-positive. Gelatin, starch and casein not hydrolysed. Tweens 20, 60 and 80 hydrolysed. Nitrate reduced to nitrite. Indole not produced. Amino acids are utilized. Glucose, lactose, mannose, sucrose, maltose, sorbose, mannitol, starch, succinate and acetate are used as carbon sources. Sensitive to polymycin and novobiocin and insensitive to penicillin, chloramphenicol, streptomycin, tetracycline, ampicillin, rifampicin, erythromycin, bacitracin, neomycin and sulphafurazole. The polar lipids are $\mathrm{C}_{20} \mathrm{C}_{20}$ and $\mathrm{C}_{20} \mathrm{C}_{25}$ diether derivatives of PG and PGP-Me with five uncharacterized minor phospholipids. The $\mathrm{G}+\mathrm{C}$ content of the DNA is $63 \cdot 3 \mathrm{~mol} \%\left(T_{\mathrm{m}}\right)$. The type strain, $8 \mathrm{~W} 8^{\mathrm{T}}\left(=\mathrm{AS} 1.3239^{\mathrm{T}}=\mathrm{JCM} 11889^{\mathrm{T}}\right)$ was isolated from Lake Zabuye (soda lake). The GenBank accession number of the 16S rRNA is AY149598.

\section{Acknowledgements}

This work was supported by grants from the Chinese Academy of Sciences (Knowledge Innovation Program), the Ministry of Science and Technology of China (863 Programs) and the European 
Commission ('Biotechnology of Extremophiles', contract no. BIO2CT93-0274 and 'Multigenome Access Technology for Industrial Catalysts', contract no. QLK3-CT-2002-01972).

\section{References}

Franzmann, P. D., Stackebrandt, E., Sanderson, K., Volkman, J. K., Cameron, D. E., Stevenson, P. L., McMeekin, T. A. \& Burton, H. R. (1988). Halobacterium lacusprofundi sp. nov., a halophilic bacterium isolated from Deep Lake, Antarctica. Syst Appl Microbiol 11, 20-27.

Grant, W. D., Kamekura, M., McGenity, T. J. \& Ventosa, A. (2001). Order I. Halobacteriales. In Bergey's Manual of Systematic Bacterio$\log y$, 2nd edn, vol. 1, pp. 294-334. Edited by D. R. Boone, R. W. Castenholz \& G. M. Garrity. New York: Springer.

Holland, H. D., Smith, G. I., Jannasch, H. W., Dickson, A. G., Zheng, M. \& Ding, T. (1991). Lake Zabuye and the climatic history of the Tibetan Plateau. Geowissenschaften 9, 37-44 (in German).

Huß, V. A. R., Festl, H. \& Schleifer, K. H. (1983). Studies on the spectrophotometric determination of DNA hybridization from renaturation rates. Syst Appl Microbiol 4, 184-192.

Kamekura, M. \& Dyall-Smith, M. L. (1995). Taxonomy of the family Halobacteriaceae and the description of two new genera Halorubrobacterium and Natrialba. J Gen Appl Microbiol 41, 333-350.

Kamekura, M., Dyall-Smith, M. L., Upasani, V., Ventosa, A. \& Kates, M. (1997). Diversity of alkaliphilic halobacteria: proposals for transfer of Natronobacterium vacuolatum, Natronobacterium magadii, and Natronobacterium pharaonis to Halorubrum, Natrialba, and Natronomonas gen. nov., respectively, as Halorubrum vacuolatum comb. nov., Natrialba magadii comb. nov., and Natronomonas pharaonis comb. nov., respectively. Int J Syst Bacteriol 47, 853-857.

Lizama, C., Monteoliva-Sanchez, M., Suarez-Garcia, A., RoselloMora, R., Aguilera, M., Campos, V. \& Ramos-Cormenzana, A. (2002). Halorubrum tebenquichense sp. nov., a novel halophilic archaeon isolated from the Atacama Saltern, Chile. Int J Syst Evol Microbiol 52, 149-155.

McGenity, T. J. \& Grant, W. D. (1993). The haloalkaliphilic archaeon (archaebacterium) Natronococcus occultus represents a distinct lineage within the Halobacteriales, most closely related to the other haloalkaliphilic lineage (Natronobacterium). Syst Appl Microbiol 16, 239-243.
McGenity, T. J. \& Grant, W. D. (1995). Transfer of Halobacterium saccharovorum, Halobacterium sodomense, Halobacterium trapanicum NRC 34021 and Halobacterium lacusprofundi to the genus Halorubrum gen. nov., as Halorubrum saccharovorum comb. nov., Halorubrum sodomense comb. nov., Halorubrum trapanicum comb. nov., and Halorubrum lacusprofundi comb. nov. Syst Appl Microbiol 18, 237-243.

Mwatha, W. E. \& Grant, W. D. (1993). Natronobacterium vacuolata sp. nov., a haloalkaliphilic archaeon isolated from Lake Magadi, Kenya. Int J Syst Bacteriol 43, 401-404.

Oren, A. (1983). Halobacterium sodomense sp. nov., a Dead Sea halobacterium with an extremely high magnesium requirement. Int J Syst Bacteriol 33, 381-386.

Oren, A. \& Ventosa, A. (1996). A proposal for the transfer of Halorubrobacterium distributum and Halorubrobacterium coriense to the genus Halorubrum as Halorubrum distributum comb. nov. and Halorubrum coriense comb. nov., respectively. Int J Syst Bacteriol 46, 1180.

Oren, A., Ventosa, A. \& Grant, W. D. (1997). Proposed minimal standards for description of new taxa in the order Halobacteriales. Int J Syst Bacteriol 47, 233-238.

Petter, H. F. M. (1931). On bacteria of salted fish. Proc K Ned Akad Wet Amsterdam 34, 1417-1423 (in Dutch).

Ross, H. N. M., Collins, M. D., Tindall, B. J. \& Grant, W. D. (1981). A rapid procedure for the detection of archaebacterial lipids in halophilic bacteria. J Gen Microbiol 123, 75-80.

Thompson, J. D., Higgins, D. G. \& Gibson, T. J. (1994). CLUSTAL W: improving the sensitivity of progressive multiple sequence alignments through sequence weighting, position-specific gap penalities and weight matrix choice. Nucleic Acids Res 22, 4673-4680.

Tindall, B. J., Mills, A. A. \& Grant, W. D. (1980). An alkalophilic red halophilic bacterium with a low magnesium requirement from a Kenyan soda lake. J Gen Microbiol 116, 257-260.

Tomlinson, G. A. \& Hochstein, L. I. (1976). Halobacterium saccharovorum sp. nov., a carbohydrate-metabolizing extremely halophilic bacterium. Can J Microbiol 22, 587-591.

Van de Peer, Y. \& De Wachter, R. (1994). TREECON for Windows: a software package for the construction and drawing of evolutionary trees for the Microsoft Windows environment. Comput Appl Biosci 10, 569-570.

Zvyagintseva, I. S. \& Tarasov, A. L. (1987). Extreme halophilic bacteria from saline soils. Mikrobiologiya 56, 839-844 (in Russian). 